\title{
X-linked hypophosphatemia and growth
}

\section{R. Fuente, H. Gil-Peña, D. Claramunt-}

Taberner, O. Hernández, A. FernándezIglesias, L. Alonso-Durán, E. RodríguezRubio, et al.

Reviews in Endocrine and Metabolic Disorders

ISSN 1389-9155

Rev Endocr Metab Disord DOI 10.1007/s11154-017-9408-1

\section{ONLINE FIRST}

REVIEWS IN ENDOCRINE

\& METABOLIC DISORDERS

EDITOR:

CHRISTIAN KOCH

Endocrinological Aspects of Andrology-What is New? Guest Editor: Michael Zitzmann

Springer

勿 Springer 
Your article is protected by copyright and all rights are held exclusively by Springer Science +Business Media New York. This e-offprint is for personal use only and shall not be selfarchived in electronic repositories. If you wish to self-archive your article, please use the accepted manuscript version for posting on your own website. You may further deposit the accepted manuscript version in any repository, provided it is only made publicly available 12 months after official publication or later and provided acknowledgement is given to the original source of publication and a link is inserted to the published article on Springer's website. The link must be accompanied by the following text: "The final publication is available at link.springer.com". 


\title{
X-linked hypophosphatemia and growth
}

\author{
R. Fuente ${ }^{1} \cdot$ H. Gil-Peña ${ }^{2}$ - D. Claramunt-Taberner ${ }^{1} \cdot$ O. Hernández ${ }^{1}$. \\ A. Fernández-Iglesias ${ }^{1} \cdot$ L. Alonso-Durán ${ }^{1} \cdot$ E. Rodríguez-Rubio $^{1} \cdot$ F. Santos $^{1,2}$
}

(C) Springer Science+Business Media New York 2017

\begin{abstract}
X-Linked hypophosphatemia (XLH) is the most common form of hereditary rickets caused by loss-of function mutations in the PHEX gene. XLH is characterized by hypophosphatemia secondary to renal phosphate wasting, inappropriately low concentrations of 1,25 dihydroxyvitamin $\mathrm{D}$ and high circulating levels of fibroblast growth factor 23 (FGF23). Short stature and rachitic osseous lesions are characteristic phenotypic findings of XLH although the severity of these manifestations is highly variable among patients. The degree of growth impairment is not dependent on the magnitude of hypophosphatemia or the extent of legs' bowing and height is not normalized by chronic administration of phosphate supplements and $1 \alpha$ hydroxyvitamin D derivatives. Treatment with growth hormone accelerates longitudinal growth rate but there is still controversy regarding the potential risk of increasing bone deformities and body disproportion. Treatments aimed at blocking FGF23 action are promising, but information is lacking on the consequences of counteracting FGF23 during the growing period. This review summarizes current knowledge on phosphorus metabolism in XLH, presents updated information on XLH and growth, including the effects of FGF23 on epiphyseal growth plate of the Hyp mouse, an animal model of the disease, and discusses growth hormone and novel FGF23 related therapies.
\end{abstract}

F. Santos

fsantos@uniovi.es

1 Division of Pediatrics, Department of Medicine. Faculty of Medicine, University of Oviedo, Oviedo, Asturias, Spain

2 Department of Pediatrics, Hospital Universitario Central de Asturias (HUCA), Oviedo, Asturias, Spain
Keywords Phosphate $\cdot$ Rickets $\cdot$ Growth $\cdot$ Bone $\cdot$ Growth plate $\cdot$ Hypophosphatemia

\section{Phosphate homeostasis}

Phosphate is an essential mineral, indispensable for a normal bone and tooth development, it is critical for a wide array of cellular processes and it is an integral component of the nucleic acids. Normal values of serum phosphate in adults vary from 2.4 to $4 \mathrm{mg} / \mathrm{dL}$ whereas children have higher levels, i.e. between $4.8-7.4 \mathrm{mg} / \mathrm{dL}$ in the first 3 months of life and between $4.5-5.8 \mathrm{mg} / \mathrm{dL}$ at $1-2$ years [1]. In mammals including humans, circulating concentration of inorganic phosphate (Pi) is determined by renal and intestinal (predominantly in the jejunum) uptakes and by its distribution between bone and soft tissues [2]. To maintain a neutral balance, the amount of absorbed phosphate has to be equal to the amount excreted in the urine. Approximately, $75-85 \%$ of the phosphorus filtrated by the glomeruli is reabsorbed in the proximal tubule. This reabsorption of filtrated $\mathrm{Pi}$ is carried out by sodium-coupled phosphate (NaPi) co-transporters localized at the apical membrane of tubular cells [3]. In the brush border membrane three cotransporters have been identified so far: NaPi-IIa (gen SLC34A1), NaPi-IIc (gen SLC34A3) and, more recently, Pit2 (gen SLC20A2) [3-5]. In the intestine, NaPi-IIb cotransporter mediates the transcellular phosphate transport.

The serum phosphate concentration is regulated by parathyroid hormone $(\mathrm{PTH})$ and 1,25 dihydroxyvitamin $\mathrm{D}$ $\left[1,25(\mathrm{OH})_{2} \mathrm{D}\right]$. PTH decreases the proximal tubular reabsorption of phosphate by reducing $\mathrm{NaPi}$-IIa and $\mathrm{NaPi}$-IIc activities. This reduction is achieved by internalization of $\mathrm{NaPi}$ proteins from the lumen side of the proximal tubular epithelial cells [6]. PTH also mobilizes phosphate from the skeletal into the bloodstream, possibly by enhancing osteoclastic bone resorption. In 
addition, PTH increases the production of $1,25(\mathrm{OH})_{2} \mathrm{D}$ by inducing the renal expression of 1- $\alpha$-hydroxylase (CYP27B1) and stimulates intestinal phosphate absorption [7]. CYP27B1 enzyme, located in the proximal tubule of the kidney and a variety of other tissues, including bone osteoblasts [8], catalyzes the hydroxylation of 25 hydroxyvitamin $\mathrm{D}$ to $1,25(\mathrm{OH})_{2} \mathrm{D}$, the bioactive form of vitamin $\mathrm{D}$.

In addition to PTH and vitamin D, other hormones can affect renal phosphate handling. Growth hormone, insulin, and thyroid hormone all increase phosphate tubular reabsorption, whereas calcitonin, glucocorticoids, and atrial natriuretic factor decrease it.

The major recent breakthrough in understanding the active regulation of phosphate homeostasis was accomplished by the identification of fibroblast growth factor 23 (FGF23). FGF23 is an hormone mainly synthesized by osteocytes, but it has also been identified in the endothelial cells of the venous sinusoids of the bone marrow and in the thymus of Hyp mouse [9]. Its synthesis and secretion are positively regulated by vitamin $\mathrm{D}$ and serum phosphorus $[10,11]$. When phosphorus levels are too high, FGF23 inhibits the renal tubular reabsorption. FGF23 suppresses CYP27B1 transcription in the kidney activity and stimulates catabolism of $1,25(\mathrm{OH})_{2} \mathrm{D}$ through 24 hydroxylase enzyme (CYP24) (Fig. 1). Although elevated FGF23 levels are involved in the pathogenesis of some forms of hereditary and acquired hypophosphatemic rickets [12], its physiological role in the regulation of phosphate metabolism is still to be defined.

The protein klotho $(\mathrm{KL})$ has been found to be critical for FGF23 signaling [13]. Klotho is an essential cofactor for FGF23. Membrane-bound-klotho interacts with FGF receptors (FGFR) in proximal tubular cells to form a high affinity receptor for FGF23. FGFR4 or the IIIc isoforms of FGFR1 and FGFR3 [14-16] form an heteromeric complex, FGF23-KLFGFR, which activates the mitogen activated protein kinase (MAPK) cascade and induces the phosphorylation of ERK1/ 2 (p-ERK1/2) [17, 18]. In the end, activation of this pathway results in the reduction of NaPi-IIa and $\mathrm{NaPi}$-IIc protein expression in the kidney (Fig. 2) and in the inhibition of $1,25(\mathrm{OH})_{2} \mathrm{D}$ synthesis [19]. Reduction of the $1,25(\mathrm{OH})_{2} \mathrm{D}$ levels may lead to a decrease in intestinal type $\mathrm{NaPi}-\mathrm{IIb}$ transporter and also to a reduction of intestinal Pi absorption. In fact, KL-knockout mice exhibit overexpression of NaPi-IIa and $\mathrm{NaPi}$-IIc proteins with concomitant hyperphosphatemia [20].

Interestingly, $\mathrm{KL}$ exists also as a circulating form that likely has a distinct mode of action. Recent studies have shown that secreted KL can act independently from FGF23 and directly inactivate the expression of $\mathrm{NaPi}$-IIa inducing phosphaturia $[21,22]$. It has been suggested that secreted KL can influence $\mathrm{Na}^{+}-\mathrm{K}^{+}$-ATPase activity, which results in an increased $\mathrm{Na}^{+}$ion gradient and enhances trans-epithelial calcium transport in the choroid plexus and the kidneys [23]. Indeed, secreted KL has been shown to increase the tubular cell surface expression of
TRPV5 [24, 25], a channel involved in calcium reabsorption, probably through FGFR1 and ERK 1/2 WNK4 pathway.

\section{X-linked hypophosphatemia}

X-Linked hypophosphatemia (XLH) (OMIM 307800) is the most prevalent form of hereditary rickets and the most common inherited defect of renal tubular phosphate transport in humans [26, 27]. Its frequency has been estimated to be 1 in 20,000 . XLH is characterized by hypophosphatemia secondary to renal phosphate wasting, inappropriately low concentrations of $1,25(\mathrm{OH})_{2} \mathrm{D}$ and high levels of FGF23. Although there is a large phenotypic variability, XLH patients exhibit some degree of disproportional dwarfism with predominant shortening of lower limbs, low mineral density and rickets or osteomalacia $[28,29]$.

\subsection{Genetic basis}

$\mathrm{XLH}$ is caused by loss of function of the PHEX gene and its transmission follows a X-dominant heritance [30-32]. A wide array of mutations has been described [33], and among them a significant number of sporadic cases resulting from de novo PHEX mutations [34, 35]. The PHEX gene has 22 exons and encodes a 749-amino acid protein that putatively consists of an intracellular, transmembrane, and extracellular domain. The Hyp-mouse, discovered in 1976 by Eva M. Eicher, is the best completely characterized animal model of XLH [29, 30]. Hyp gene is homologous with the X-linked human gene, which encodes a protein that belongs to the neutral endopeptidase family of zinc metalloproteinase [34]. Studies in the Hyp mouse have shown that Phex is expressed chiefly in osteoblast and osteoclast of bone and teeth but also in lung, brain, ovary, testicle and muscle $[31,36]$.

\subsection{Biochemical and molecular findings}

Characteristic biochemical findings of XLH are hypophosphatemia secondary to decreased tubular reabsorption of phosphate, insufficiently high concentrations of serum $1,25(\mathrm{OH})_{2} \mathrm{D}$, elevated circulating levels of FGF23 and normal serum calcium and PTH [37]. Serum alkaline phosphatase, a marker of bone formation, is elevated in children who develop rickets, and usually returns to normal in adulthood.

Studies carried out in parathyroidectomized Hyp mice indicated that the exacerbated phosphaturia is not caused by PTH [38] but more likely results from the decreased expression of the Pi transporters [39]. The identification of FGF23 has disclosed a major role of this hormone in the pathogenesis of the disease. Elevated circulating levels of FGF23 have been noted in Hyp mice [40] as well as in XLH patients [41]. Probably FGF23 increases renal phosphate excretion by 


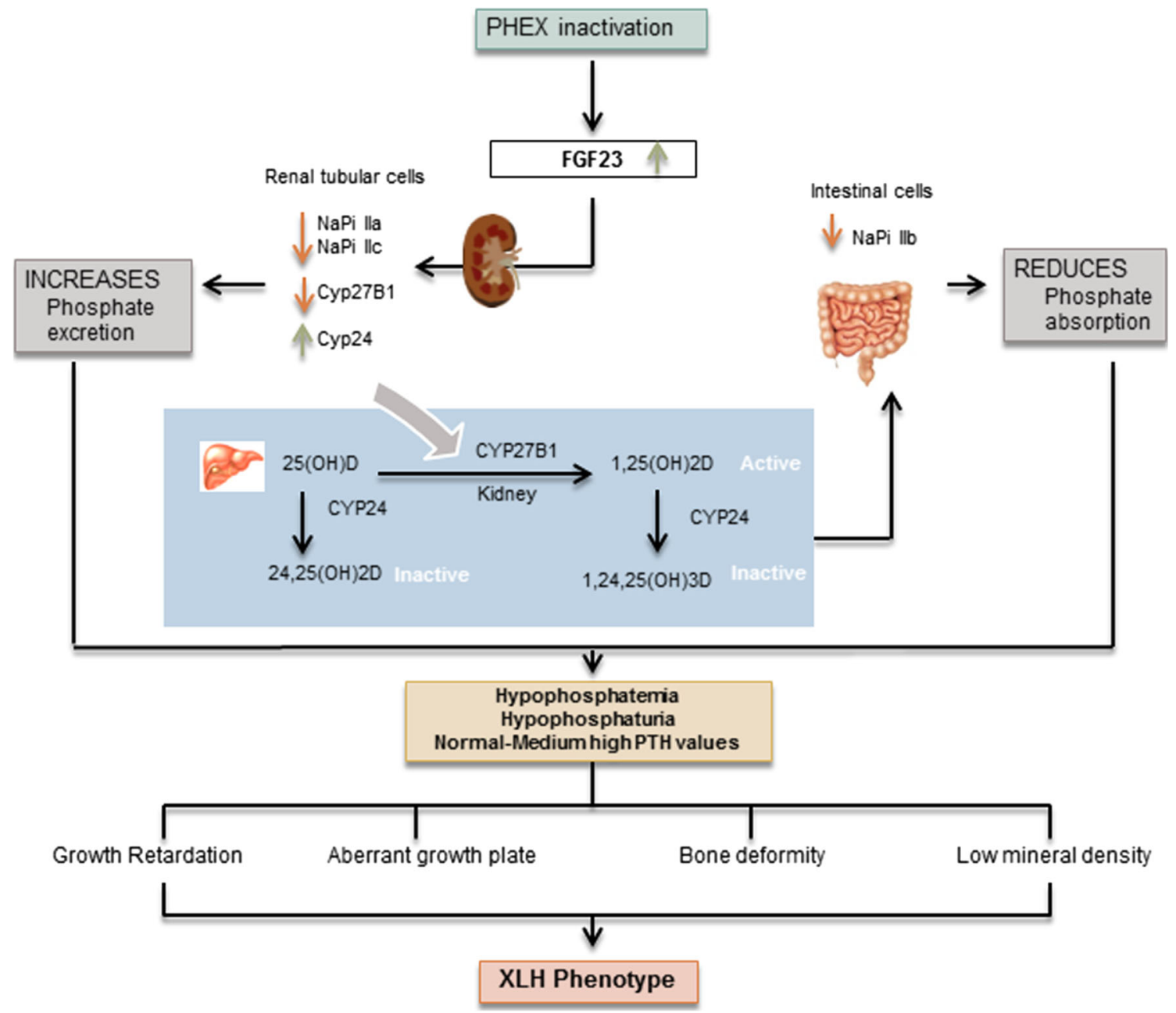

Fig. 1 Phosphorus metabolism in XLH. Inactivation of PHEX gene results in increased circulating levels of FGF23. FGF23 directly suppresses renal sodium-phosphate cotransporters (NaPi-IIa and NaPiIIc) and increases the urinary excretion of phosphate. Likewise, FGF23 suppresses the expression of 1- $\alpha$ hydroxylase (CYP27B1) and stimulates the production of 24-hydroxylase (CYP24), so reducing $1,25(\mathrm{OH})_{2} \mathrm{D}$ levels and hence the phosphate intestinal absorption mediated by

reducing expression and activity of $\mathrm{NaPi}$ cotransporters as well as by inhibiting the CYP27B1 enzyme [42] (Fig. 1).

As PHEX is the only gene having pathogenic variants known to cause XLH, Liu et al. (2007) examined the mechanism whereby FGF23 is regulated by Phex in transplanting Hyp bones in wild type mice and vice-versa [40]. They found that wild type bone explanted into Hyp mice developed osteomalacia and failed to normalize systemic FGF23 levels, suggesting that the defective bone mineralization was caused by circulating factors. On the other hand, FGF23 was increased in Hyp osteocytes before and after explantation into wild type mice, but it was not modified in wild type mouse osteocytes after explantation into Hyp mice, suggesting that FGF23 overexpression resulted from an intrinsic bone Phex defect. Unexpectedly, they also observed a paradoxical suppression of FGF23 in juvenile Hyp bone explanted into adult Hyp sodium-phosphate cotransporter NaPi-IIb. Prolonged phosphate restriction it should increase not only $1,25(\mathrm{OH})_{2} \mathrm{D}$ level but also PTH, nevertheless XLH is associated with normal or slightly elevated serum parathyroid hormone. Therefore PHEX inactivation induces hyperphospaturia and Hypophosphatemia and in the end XLH patients develop bone complications and growth retardation

mice, indicating the presence of an age-dependent systemic inhibitor of FGF23 that can be the real PHEX substrate. This finding could explain why the disease appears to lessen in severity with age $[43,44]$. In addition, FGF23 levels are highly variable in XLH patients [45], supporting the presence of others factors that regulate FGF23. It remains unclear how loss of function of PHEX results in elevated FGF23 levels.

\subsection{XLH and growth}

Short stature is a phenotypic hallmark of XLH. Adults with XLH have a significantly reduced final height up to $20 \mathrm{~cm}$, mean standard deviation score (SDS) of -1.9 [44], but there is a great variability among individuals. XLH patients are not abnormally small at birth [46]; XLH girls and boys seem to have normal growth spurt and adult men show a more severe 

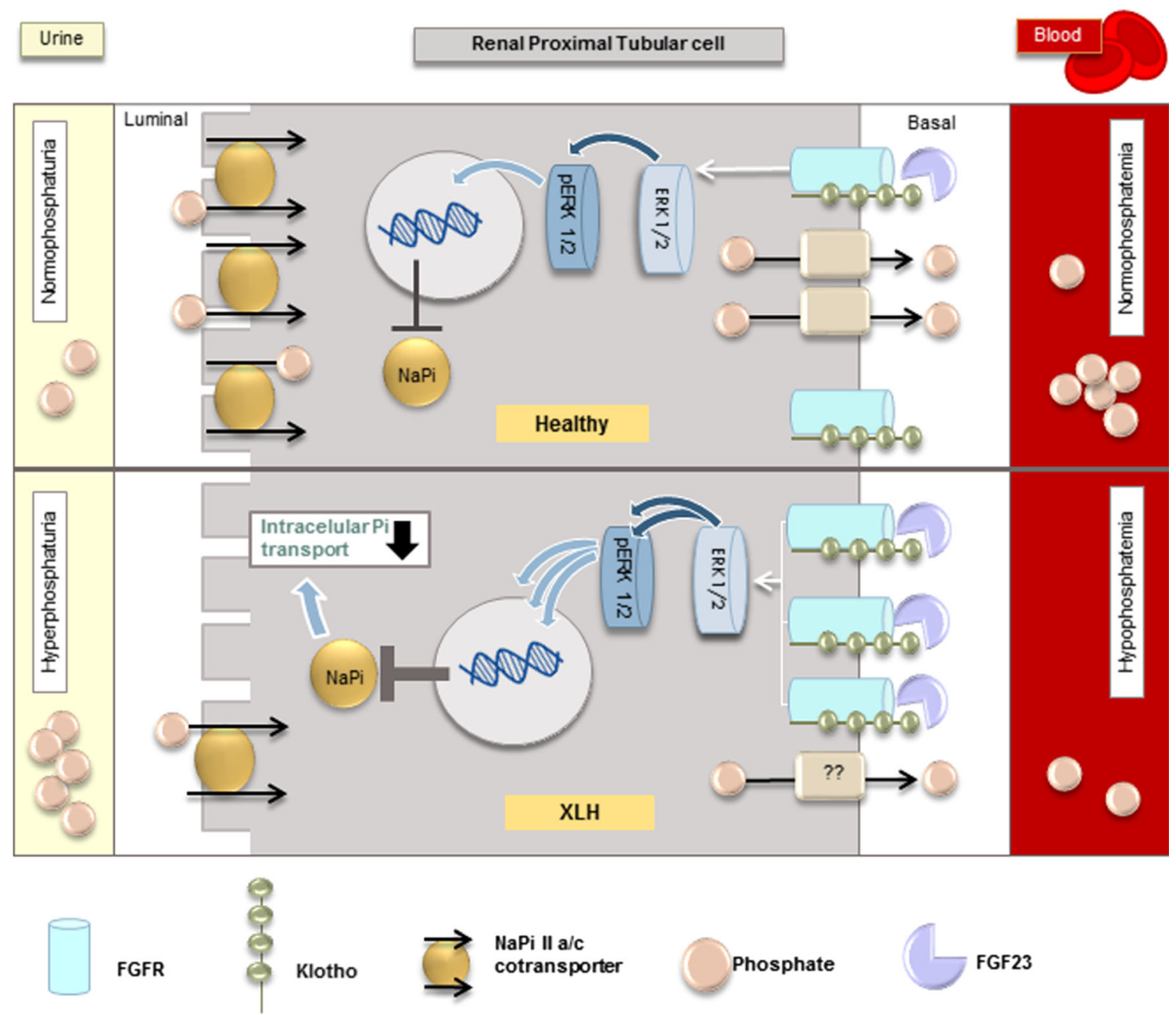

Fig. 2 Model of FGF23- $\alpha$ Klotho signaling in renal distal tubular cells. This figure shows the possible mode of action of FGF23/klotho in producing hypophosphatemia and hyperphospaturia in XLH renal proximal tubular cell. FGF23 binds to the basolateral FGFR-Klotho complex in proximal tubular cells and activates ERK1/2 by phosphorylation. pERK1/ 2 acts on the nucleus and induced a downregulation of $\mathrm{NaPi}-\mathrm{IIa} / \mathrm{c}$

XLH phenotype than women [46-49]. Otherwise, serum phosphate concentrations and stature SDS have been shown to keep a poor positive correlation in children with XLH. Adults who began treatment with phosphate and $1,25(\mathrm{OH})_{2} \mathrm{D}$ earlier, manage to grow taller despite having a similar degree of hypophosphatemia [50, 51]. In this regard, Jehan et al. (2008) described changes in growth that are associated with different vitamin D receptor promoter haplotypes, providing a possible explanation for some of the clinical variability observed in XLH [52]. On the other hand, defects in growth hormone $(\mathrm{GH})$ secretion have been reported in only a few patients [47], and associated metabolic, inflammatory or nutritional disorders have not been described in XLH individuals. Thus, the adverse effect of XLH on growth seems to be not dependent on GH disordered metabolism or nutritional deficiencies. cotransporters expression. In a XLH cell, the pathogenic high levels of FGF23 lead to ERK1/2 over-activation and to a dramatic reduction of $\mathrm{NaPi}$ II a/c expression. Low presence of $\mathrm{NaPi}$ cotransporters in the apical border membrane reduces the intracellular transport of phosphate in proximal tubular cells, increment the phosphate excretion through the urine and leads to the hyperphospaturia and hypophosphatemia

A relevant point is that dwarfism of XLH patients is disproportional, longitudinal shortening and the degree of the deformity being more severe in lower extremities than in the rest of the body [44, 50,53] Bowing and/or twisting tend to appear once a child begins to bear weight on his or her legs. In fact, the diagnosis is frequently made in the first two years of life, when lower-extremity bowing becomes evident. Corrective surgical osteotomy is often required when correction of the torsion is not reversed by medical therapy. Nevertheless, it is not clear that growth retardation can be only explained by the bone bowing itself.

Bone mineral density is also decreased in children and adolescents [54], often persists low into adulthood, and not always improves with standards therapies $[43,54,55]$. This bone weakness may affect the child's daily life and increases the possibility of developing arthritis over the years. Qiu et al. 
(2004) showed in Hyp mice that there were not gender differences in bone mineral accrued between males and females Hyp mice, but there were differences in vertebra length, indicating that long bones' rickets and osteomalacia follow different mechanism and are not equally affected by gen dose [56].

Epiphyseal growth plate is responsible for the longitudinal endochondral ossification and determines the final length of bones. Defects in the development of this organ or fractures can lead to growth complications. Physiologically, the rate and extent of growth are determined by the combination of chondrocyte proliferation, matrix production, and enlargement of hypertrophic chondrocytes [57]. The finding that PHEX is strongly expressed not only by osteoblasts, but also by chondrocytes, and its expression is influenced by transcription factor of chondrogenesis [58], suggests that the loss of PHEX function might directly contribute to the pathogenesis of growth retardation and cartilage abnormalities. The anatomic characteristics of the growth plate make its study extremely difficult in the clinical setting and justify the use of animal models for a better understanding of the mechanisms interfering with normal growth in XLH patients. Hyp mice have profound abnormalities in the growth plate although a detailed analysis of the structure and dynamics of growth plate cartilage in this animal model of XLH remains to be performed. It is known that epiphyseal growth plates are proximally-distally thicker than normal growth plates [59]. These findings suggest that the primary skeletal defect in Hyp mice is not caused by abnormal osteoblast differentiation but rather by an impairment in mineralization by osteoblasts [60]. Recent findings indicate that FGF21, a member of the FGF family that like FGF23 functions as an endocrine factor, directly inhibits chondrocyte proliferation and differentiation at the growth plate; so that FGF23 might be playing a causal role in the abnormal process of growth plate [61].

Studies in humans and mice raised the question as to whether normalization of serum calcium, phosphate, or both was required to normalize the growth plate phenotype and therefore the final length. The calcium sensing receptor $\mathrm{KO}$ mouse CasR (a murine model of familial hypercalcemia) has high serum calcium, low circulating phosphate levels and develops a rachitic growth plate in the presence of hyperparathyroidism. However, when this mouse is mated with a Gcm2null-mouse (mice lacking parathyroid glands) [62], resulting mice develop hypocalcemia combined with normophosphatemia and mild hypoparathyroidism. Therefore, it can be concluded that the correction of PTH and Pi levels are crucial for a normal cartilage development [63]. Sabbagh et al. (2005) found decreased apoptosis rate, assessed by TUNEL technique and cleaved caspase 3 activity in hypertrophic chondrocytes of Hyp mouse versus wild type mouse growth plate [64], demonstrating that normal phosphorus levels are also required for hypertrophic chondrocyte cell death. Likewise Shiguang Liu et al. (2007) explanted Hyp bones in wild type mice showing that Hyp bones near normalized the growth plate width [40] when they are in a normal phosphorus environment.

Thus, all these studies point to phosphate as well as FGF23 as important regulators of growth plate maturation and bone formation [65].

\subsection{XLH treatment}

In humans, growth deceleration and rickets in XLH begin to occur during the first 2 years of age when the growth velocity is physiologically maximum. Therefore, the early initiation of treatment is essential, before overt manifestation of rickets and growth retardation develop [46]. Pharmacologic treatment in XLH patients consists of oral phosphate supplementation and 1-alpha hydroxyvitamin D derivatives' administration. Although this therapy usually leads to an improvement of biochemical parameters and amelioration of rickets [66], the effects on longitudinal growth are often disappointing and some patients remain unresponsive [55]. On the other hand, the risk of hypercalcemia, hypercalciuria, hyperparathyroidism and nephrocalcinosis as well as the gastrointestinal tolerance to phosphate limit the progressive increase in the doses of 1- $\alpha$ hydroxyvitamin $\mathrm{D}$ derivatives and phosphate [67, 68]. Recent data from a multi-center Austrian - German study on 76 children with XLH showed progressive deterioration of height, expressed as SDS, despite continued treatment with phosphate and calcitriol [50]. Another study in 23 adult patients showed a decreased joint mobility despite the treatment with vitamin D and phosphorus [43]. It is also of note that, despite inappropriate baseline elevations in FGF23 concentrations in XLH patients, standard treatment with calcitriol and phosphate further increases levels of this hormone $[69,70]$.

\subsubsection{Growth hormone treatment}

Pediatric patients with XLH have been treated with recombinant human GH (rhGH) [71]. Maintained doses of rhGH have shown an improvement in growth velocity and phosphate concentrations [46, 48, 50, 72], however, there are not clear evidences about the effectiveness of the treatment [50]. A 3year-study carried out by Haffner et al. (2004) in rhGH treated children showed potential hormone benefit over the final height but failure to normalize the body disproportion [73]. In poorly growing XLH patients, rhGH therapy added to the conventional treatment with vitamin $\mathrm{D}$ metabolites and phosphate improved final height, phosphate retention and radial bone mineral density but did not modify the disharmonic development [48]. Animal studies have mostly focused on examine the short-term effect of GH treatment on vitamin D metabolism and renal phosphate transport [74] rather than the long-term effect on growth. 


\subsubsection{New FGF23 related therapies}

Tumor induced osteomalacia (TIO) has been proposed to have an overlapping pathophysiology with $\mathrm{XLH}$, since $P H E X$ is also present in the tumors, raising the possibility that TIO and XLH share components of a common pathogenic mechanism. In fact, in some TIO patients high levels of FGF23 have been identified to cause osteomalacia as well as hypophosphatemia $[75,76]$. It would be of interest to know whether the inhibition of FGF23 activity is useful or not for patients with hypophosphatemic rickets/osteomalacia caused by excessive activity of FGF23 [77]. In this respect there are not many studies in Hyp mouse [78-84] and only two in humans $[85,86]$.

Two studies in wild type and Hyp mice have shown that the inhibition of the FGFR effectively blocks FGF23 function and it partially corrects the hypophosphatemia of the mutant mouse [77, 78]. Wöle et al. (2013) have assessed the potential use of FGFR inhibitors during long term periods in Hyp mice. They used NVP-BGJ398, a novel FGFR inhibitor, currently being used in phase I clinical trials as cancer therapy. Drug was orally administered during 5 weeks in adult Hyp mice [80] leading to enhanced bone growth, increased mineralization, and reorganization of the disturbed growth plate structure.

As for FGF23 inhibition, a single dose of anti-murine FGF23 antibody given to Hyp mice increased serum calcitriol whereas repeated injections ameliorated rickets and bone mineralization [81, 82]. In the only prolonged study in humans, 4month administration of KRN23 (a recombinant human IgG1 monoclonal antibody that binds to FGF23 and blocks its biological activity) resulted in significantly increased serum phosphate, renal phosphate reabsorption, and circulating $1,25(\mathrm{OH})_{2} \mathrm{D}$ concentrations in 28 XLH adult patients [85].

It has also been shown that MAPK signaling mediated by ERK $1 / 2$ is necessary for the suppressive effects of FGF 23 on renal Pi reabsorption and calcitriol production [17, 80, 83] (Fig. 2). In Hyp mice, Zang et al. (2012) showed that the inhibition of this pathway, improved serum phosphate and $1,25(\mathrm{OH})_{2} \mathrm{D}$ concentrations as well as osseous lesions of rickets or osteomalacia regardless the persistently elevated systemic levels of FGF23 [84]. They hypothesized that other molecules apart from FGF23 must be contributing to the pathogenesis of the disease. In this regard, crossing mice homozygous for the null Cyp24 allele, the mitochondrial enzyme responsible for inactivating $1,25(\mathrm{OH})_{2} \mathrm{D}$, with Hyp mice [79] led to offspring having high circulating levels of FGF23 but lacking CYP24 enzymatic activity. In these animals, serum concentrations of phosphate and $1,25(\mathrm{OH})_{2} \mathrm{D}$ did not improve but the rachitic/osteomalacic bone abnormalities and abnormal growth plate were ameliorated independently of the levels of FGF23. Thus, bone and growth plate disturbances in XLH may be dependent on the autocrine/ paracrine effects of vitamin $\mathrm{D}$ rather than on circulating phosphorus and FGF23 levels.

\section{Areas of research and development}

$\mathrm{XLH}$, the most prevalent inherited rickets, is caused by loss of function of the PHEX gene and biochemically characterized by low serum phosphate concentration, reduced tubular reabsorption of phosphate and high circulating levels of FGF23. The mechanisms whereby inactivation of $P H E X$ causes these alterations remain unclear.

XLH patients show a wide phenotypic variability but short stature and body disproportion with some degree of legs' bowing are key clinical manifestations. The reason for growth impairment in XLH is not completely clear because the reduction in height does not entirely depend on the severity of lower extremities' deformity. It is of note that few data are available on the abnormalities of the growth plate in XLH, even in the Hyp mouse which is a good animal model of the disease. The impact of XLH on the normal structure and dynamics of growth plate chondrocytes and the relationship of these alterations on longitudinal growth rate are areas of further research.

Height is not normalized by sustained treatment with phosphate and calcitriol and although GH therapy has been shown to accelerate growth velocity there are some concerns on its potential to exaggerate body disproportion. Studies on the administration of GH in Hyp mice have mostly focused on the ability of GH to improve phosphate and vitamin D metabolism but there is a lack of information on its effects on growth plate. In addition, treatments aimed at blocking FGF23 action are promising but, again, information is lacking on the consequences of counteracting FGF23 on the growth plate.

In conclusion, despite rickets and bone bowing being the most noticeable symptoms of the XLH disorder, most of the treatments are focused on phosphorus and vitamin D metabolism. Consequently, it is essential to understand the mechanism underlying the growing impairment and how conventional and new treatments affect in this regard.

Acknowledgements This work was supported by the National Plan I+ D + I 2008-2011, Instituto de Salud Carlos III (PI12/00987) and also by the National Plan I + D + I 2013-2016 Instituto de Salud Carlos III (PI14/00702 and PI15/02122), European Regional Development Funds 2013-2016 (ERDF, Grupín 14-020) and by the Foundation of the University of Oviedo (FUO).

Compliance with ethical standards The article did not involve human or animal participation. Therefore, informed consent or IRB approval were not needed.

Conflict of interest The authors declare that they have no conflict of interest.

-The manuscript has not been submitted to more than one journal.

-The manuscript has not been published previously.

- No data/figures have been fabricated or manipulated.

-A single study is not split up into several parts.

- No data, text or theories are being plagiarized.

-All authors have been informed about the submission of the paper and all have contributed to the article. 


\section{References}

1. Santos F, Fuente R, Mejia N, Mantecon L, Gil-Peña H, Ordoñez FA. Hypophosphatemia and growth. Pediatric Nephrology. 2013;28:595-603.

2. Wagner CA, Rubio-Aliaga I, Biber J, Hernando N. Genetic diseases of renal phosphate handling. Nephrol Dial Transplant England. 2014;29:45-54.

3. Biber J, Stieger B, Stange G, Murer H. Isolation of renal proximal tubular brush-border membranes. Nature Protocols England. 2007;2:1356-9.

4. Marks J, Debnam ES, Unwin RJ. Phosphate homeostasis and the renal-gastrointestinal axis. American Journal of Physiology. Renal Physiology. 2010;299:285-96.

5. Villa-Bellosta R, Ravera S, Sorribas V, Stange G, Levi M, Murer H, Biber J, Forster IC. The Na + -pi cotransporter PiT-2 (SLC20A2) is expressed in the apical membrane of rat renal proximal tubules and regulated by dietary pi. American Journal of Physiology. Renal Physiology. 2009;296:691-9.

6. Forster IC, Hernando N, Biber J, Murer H. Proximal tubular handling of phosphate: a molecular perspective. Kidney International. 2006;70:1548-59.

7. Brenza HL, Kimmel-Jehan C, Jehan F, Shinki T, Wakino S, Anazawa H, Suda T, DeLuca HF. Parathyroid hormone activation of the 25-hydroxyvitamin D3-1alpha-hydroxylase gene promoter. Proceedings of the National Academy of Sciences. 1998;95:138791.

8. Kogawa M, Findlay DM, Anderson PH, Ormsby R, Vincent C, Morris HA, Atkins GJ. Osteoclastic metabolism of 25(OH)-vitamin D3: a potential mechanism for optimization of bone resorption. Endocrinology. 2010;151:4613-25.

9. Liu S, Zhou J, Tang W, Menard R, Feng JQ, Quarles LD. Pathogenic role of Fgf23 in Dmp1-null mice. American Journal of Physiology. Endocrinology and Metabolism. 2008;295:E25461 .

10. Ubaidus S, Li M, Sultana S, de Freitas PHL, Oda K, Maeda T, Takagi R, Amizuka N. FGF23 is mainly synthesized by osteocytes in the regularly distributed osteocytic lacunar canalicular system established after physiological bone remodeling. Journal of Electron Microscopy. 2009;58:381-92.

11. Quarles LD. Skeletal secretion of FGF-23 regulates phosphate and vitamin D metabolism. Nature Reviews. Endocrinology. 2012;8: 276-86.

12. Larsson T, Marsell R, Schipani E, Ohlsson C, Ljunggren O, Tenenhouse HS, Jüppner H, Jonsson KB. Transgenic mice expressing fibroblast growth factor 23 under the control of the alpha1(I) collagen promoter exhibit growth retardation, osteomalacia, and disturbed phosphate homeostasis. Endocrinology. 2004;145: 3087-94.

13. Martin A, David V, Quarles LD. Regulation and Function of the FGF23/Klotho Endocrine Pathways. Physiological Reviews. 2012;92:131-55.

14. Urakawa I, Yamazaki Y, Shimada T, Ijima K, Hasegawa H, Okawa K, Fujita T, Fukumoto S, Yamashita T. Klotho converts canonical FGF receptor into a specific receptor for FGF23. Nature. 2006;444: $770-4$.

15. Toro CL. Rol de Klotho y FGF23 en la regulación de fosfato y calcio plasmático. Rev Hosp Clin Univ Chile. 2010;23:25-32.

16. Kurosu H, Ogawa Y, Miyoshi M, Yamamoto M, Nandi A, Rosenblatt KP, Baum MG, Schiavi S, Hu MC, Moe OW, Kuro-o M. Regulation of fibroblast growth factor-23 signaling by klotho. The Journal of Biological Chemistry. 2006;281:6120-3.

17. Farrow EG, Summers LJ, Schiavi SC, McCormick JA, Ellison DH, White KE. Altered renal FGF23-mediated activity involving
MAPK and Wnt: effects of the hyp mutation. The Journal of Endocrinology. 2010;207:67-75.

18. Ornitz DM, Itoh $\mathrm{N}$. The fibroblast growth factor signaling pathway. Review of Development Biology. 2015;4:215-66.

19. Sopjani M, Rinnerthaler M, Almilaji A, Ahmeti S, DermakuSopjani M. Regulation of cellular transport by klotho protein. Current Protein \& Peptide Science. 2014;15:828-35.

20. Razzaque MS. The FGF23-klotho axis: endocrine regulation of phosphate homeostasis. Nature Reviews. Endocrinology. 2009;5:611-9.

21. Webster R, Sheriff S, Faroqui R, Siddiqui F, Hawse JR, Amlal H. Klotho/fibroblast growth factor 23- and PTH-independent estrogen receptor-alpha-mediated direct downregulation of NaPi-IIa by estrogen in the mouse kidney. American Journal of Physiology. Renal Physiology. 2016;311:F249-59.

22. Dermaku-Sopjani M, Sopjani M, Saxena A, Shojaiefard M, Bogatikov E, Alesutan I, Eichenmüller M, Lang F. Downregulation of NaPi-IIa and NaPi-Ilb Na-coupled phosphate transporters by coexpression of klotho. Cellular Physiology and Biochemistry. 2011;28:251-8.

23. Imura A, Tsuji Y, Murata M, Maeda R, Kubota K, Iwano A, Obuse C, Togashi K, Tominaga M, Kita N, Tomiyama K, Iijima J, Nabeshima Y, Fujioka M, Asato R, Tanaka S, Kojima K, Ito J, Nozaki K, Hashimoto N, Ito T, Nishio T, Uchiyama T, Fujimori T, Nabeshima Y. Alpha-klotho as a regulator of calcium homeostasis. Science. 2007;316:1615-8.

24. Chang Q, Hoefs S, Van Der Kemp AW, Topala CN, Bindels RJ, Hoenderop JG. The beta-glucuronidase klotho hydrolyzes and activates the TRPV5 channel. Science. 2005;310:490-3.

25. Andrukhova O, Smorodchenko A, Egerbacher M, Streicher C, Zeitz U, Goetz R, Shalhoub V, Mohammadi M, Pohl EE, Lanske B, Erben RG. FGF23 promotes renal calcium reabsorption through the TRPV5 channel. The EMBO Journal. 2014;33(3):229-46.

26. Burnett $\mathrm{CH}$, Dent $\mathrm{CE}$, Harper $\mathrm{C}$, Warland BJ. Vitamin d-resistant rickets. Analysis of twenty-four pedigrees with hereditary and sporadic cases. The American Journal of Medicine. 1964;36:222-32.

27. Ramussen $\mathrm{H}$, Anast C. Familial hypophosphatemic rickets and vitamin D-dependent rickets. In: Wyngaarden JB, Fredericson DS, Goldstain JL, Brrown MS, editors. The Metabolic Basis of Inherit Disease. N Y: McGraw-Hill; 1983. p. 1743-73.

28. Collins JF, Bulus N, Ghishan FK. Sodium-phosphate transporter adaptation to dietary phosphate deprivation in normal and hypophosphatemic mice. American Journal of Physics. 1995;268:917-24.

29. Eicher EM, Southard JL, Scriver CR, Glorieux FH. Hypophosphatemia - mouse model for human familial hypophosphatemic (vitamin-D-resistant) rickets. Proceedings of the National Academy of Sciences. 1976;73:4667-71.

30. Strom TM, Francis F, Lorenz B, Böddrich A, Econs MJ, Lehrach H, Meitinger T. Pex gene deletions in Gy and hyp mice provide mouse models for X-linked hypophosphatemia. Human Molecular Genetics. 1997;6:165-71.

31. Tenenhouse H. X-linked hypophosphataemia: a homologous disorder in humans and mice. Nephrology, Dialysis, Transplantation. 1999;333-41

32. Tenenhouse HS, Beck L. Renal Na +- phosphate cotransporter gene expression in X-linked hyp and Gy mice. Kidney International. 1996;49:1027-32.

33. Razali NN, Hwu TT, Thilakavathy K. Phosphate homeostasis and genetic mutations of familial hypophosphatemic rickets. Journal of Pediatric Endocrinology \& Metabolism. 2015;28:1009-17.

34. The HYP Consortium. A gene (PEX) with homologies to endopeptidases is mutated in patients with X-linked hypophosphatemic rickets. Nature Genetics. 1995;11:130-6.

35. Dixon PH, Christie PT, Wooding C, Trump D, Grieff M, Holm I, Gertner JM, Schmidtke J, Shah B, Shaw N, Smith C, Tau C, 
Schlessinger D, Whyte MP, Thakker RV. Mutational analysis of PHEX Gene in X-liked hypophosphatemia. The Journal of Clinical Endocrinology and Metabolism. 2014;83:3615-23.

36. Beck L, Soumounou Y, Martel J, Krishnamurthy G, Gauthier C, Goodyer CG, Tenenhouse HS. Pex/PEX tissue distribution and evidence for a deletion in the $3^{\prime}$ region of the Pex gene in Xlinked hypophosphatemic mice. The Journal of Clinical Investigation. 1997;99:1200.

37. Bastepe M, Juppner H. Inherited hypophosphatemic disorders in children and the evolving mechanisms of phosphate regulation. Reviews in Endocrine \& Metabolic Disorders. 2008;9:171-80.

38. Meyer RAJ, Tenenhouse HS, Meyer MH, Klugerman AH. The renal phosphate transport defect in normal mice parabiosed to Xlinked hypophosphatemic mice persists after parathyroidectomy. Journal of Bone and Mineral Research. 1989;4:523-32.

39. Tenenhouse HS, Martel J, Gauthier C, Segawa H, Miyamoto K. Differential effects of Npt2a gene ablation and X-linked hyp mutation on renal expression of Npt2c. American Journal of Physiology. Renal Physiology. 2003;285:1271-8.

40. Liu S, Tang W, Zhou J, Vierthaler L, Quarles LD. Distinct roles for intrinsic osteocyte abnormalities and systemic factors in regulation of FGF23 and bone mineralization in hyp mice. American Journal of Physiology. Endocrinology and Metabolism. 2007;293:1636-44.

41. Yamazaki Y, Okazaki R, Shibata M, Hasegawa Y, Satoh K, Tajima T, Takeuchi Y, Fujita T, Nakahara K, Yamashita T, Fukumoto S. Increased circulatory level of biologically active full-length FGF-23 in patients with hypophosphatemic rickets/osteomalacia. The Journal of Clinical Endocrinology and Metabolism. 2002;87: 4957-60.

42. Chanakul A, Zhang MY, Louw A, Armbrecht HJ, Miller WL, Portale AA, Perwad F. FGF-23 regulates CYP27B1 transcription in the kidney and in extra-renal tissues. PLoS One. 2013;8:72816.

43. Reid IR, Murphy WA, Hardy DC, Teitelbaum SL, Bergfeld MA, Whyte MP. X-linked hypophosphatemia: skeletal mass in adults assessed by histomorphometry, computed tomography, and absorptiometry. The American Journal of Medicine. 1991;90:63-9.

44. Klaus SSB, Lars B. Phenotype presentation of hypophosphatemic rickets in adults. Calcified Tissue International. 2010;87:108-19.

45. Weber TJ, Liu S, Indridason OS, Quarles LD. Serum FGF23 levels in normal and disordered phosphorus homeostasis. Journal of Bone and Mineral Research. 2003;18:1227-34.

46. Schutt SM, Schumacher M, Holterhus PM, Felgenhauer S, Hiort O. Effect of GH replacement therapy in two male siblings with combined X-linked hypophosphatemia and partial GH deficiency. European Journal of Endocrinology. 2003;149:317-21.

47. Mäkitie O, Doria A, Kooh SW, Cole WG, Daneman A, Sochett E. Early treatment improves growth and biochemical and radiographic outcome in X-linked hypophosphatemic rickets. The Journal of Clinical Endocrinology and Metabolism. 2003;88:3591-7.

48. Baroncelli GI, Bertelloni S, Ceccarelli C, Saggese G. Effect of growth hormone treatment on final height, phosphate metabolism, and bone mineral density in children with X-linked hypophosphatemic rickets. The Journal of Pediatrics. 2001;138:236-43.

49. Whyte MP, Schranck FW, Armamento-Villareal R. X-linked hypophosphatemia: a search for gender, race, anticipation, or parent of origin effects on disease expression in children. The Journal of Clinical Endocrinology and Metabolism. 1996;81:4075-80.

50. Živičnjak M, Schnabel D, Billing H, Staude H, Filler G, Querfeld U, Schumacher M, Pyper A, Schröder C, Brämswig J, Haffner D. Hypophosphatemic Rickets Study Group of Arbeitsgemeinschaft für Pädiatrische Endokrinologie and Gesellschaft für Pädiatrische Nephrologie. Age-related stature and linear body segments in children with X-linked hypophosphatemic rickets. Pediatric Nephrology. 2011;26:223-31.
51. Linglart A, Biosse-Duplan M, Briot K, Chaussain C, Esterle L, Guillaume-Czitrom S, Kamenicky P, Nevoux J, Prié D, Rothenbuhler A, Wicart P, Harvengt P. Therapeutic management of hypophosphatemic rickets from infancy to adulthood. Endocrine Connections. 2014;3:13-30.

52. Jehan F, Gaucher C, Nguyen TM, Walrant-Debray O, Lahlou N, Sinding C, Déchaux M, Garabédian M. Vitamin D receptor genotype in hypophosphatemic rickets as a predictor of growth and response to treatment. The Journal of Clinical Endocrinology and Metabolism. 2008;93:4672-82.

53. McNair, Stickler. Growth in familial hypophosphatemic vitamin-Dresistant rickets. NEJM. 1969;281:511-6.

54. Oliveri MB, Cassinelli H, Bergada C, Mautalen CA. Bone mineral density of the spine and radius shaft in children with X-linked hypophosphatemic rickets (XLH). Bone and Mineral. 1991;12:91-100.

55. Friedman NE, Lobaugh B, Drezner MK. Effects of calcitriol and phosphorus therapy on the growth of patients with X-linked hypophosphatemia. The Journal of Clinical Endocrinology and Metabolism. 1993;76:839-44.

56. Qiu ZQ, Travers R, Rauch F, Glorieux FH, Scriver CR, Tenenhouse HS. Effect of gene dose and parental origin on bone histomorphometry in X-linked hyp mice. Bone. 2004;34:134-9.

57. Hunziker EB. Mechanism of longitudinal bone growth and its regulation by growth plate chondrocytes. Microscopy Research and Technique. 1994;28:505-19.

58. Liu S, Guo R, Quarles LD. Cloning and characterization of the proximal murine Phex promoter. Endocrinology. 2001;142:3987-95.

59. Miao D, Bai X, Panda D, McKee M, Karaplis A, Goltzman D. Osteomalacia in hyp mice is associated with abnormal Phex expression and with altered bone matrix protein expression and deposition. Endocrinology. 2001;142:926-39.

60. Miao D, Bai X, Panda DK, Karaplis AC, Goltzman D, McKee MD. Cartilage abnormalities are associated with abnormal Phex expression and with altered matrix protein and MMP-9 localization in hyp mice. Bone. 2004;34:638-47.

61. Wu S, Levenson A, Kharitonenkov A, De Luca F. Fibroblast growth factor 21 (FGF21) inhibits chondrocyte function and growth hormone action directly at the growth plate. The Journal of Biological Chemistry. 2012;287:26060-7.

62. Gunther T, Chen Z-F, Kim J, Priemel M, Rueger JM, Amling M, Moseley JM, Martin TJ, Anderson DJ, Karsenty G. Genetic ablation of parathyroid glands reveals another source of parathyroid hormone. Nature. 2000;406:199-203.

63. Tu Q, Pi M, Karsenty G, Simpson L, Liu S, Quarles LD. Rescue of the skeletal phenotype in CasR-deficient mice by transfer onto the Gcm 2 null background. The Journal of Clinical Investigation. 2003;111:1029-37.

64. Sabbagh Y, Carpenter TO, Demay MB. Hypophosphatemia leads to rickets by impairing caspase-mediated apoptosis of hypertrophic chondrocytes. Proceedings of the National Academy of Sciences. 2005;102:9637-42.

65. Liu S, Zhou J, Tang W, Jiang X, Rowe DW, Quarles LD. Pathogenic role of Fgf23 in hyp mice. American Journal of Physiology. Endocrinology and Metabolism. 2006;291:38-49.

66. Ovejero D, Lim YH, Boyce AM, Gafni RI, McCarthy E, Nguyen TA, Eichenfield LF, DeKlotz CM, Guthrie LC, Tosi LL, Thornton PS, Choate KA, Collins MT. Cutaneous skeletal hypophosphatemia syndrome: clinical spectrum, natural history, and treatment. Osteoporosis International. 2016;27:3615-26.

67. Goodyer PR, Kronick JB, Jequier S, Reade TM, Scriver CR. Nephrocalcinosis and its relationship to treatment of hereditary rickets. The Journal of Pediatrics. 1987;111:700-4. 
68. Sanchez CP. Mineral metabolism and bone abnormalities in children with chronic renal failure. Reviews in Endocrine \& Metabolic Disorders. 2008;9:131-7.

69. Imel EA, DiMeglio LA, Hui SL, Carpenter TO, Econs MJ. Treatment of X-linked hypophosphatemia with calcitriol and phosphate increases circulating fibroblast growth factor 23 concentrations. The Journal of Clinical Endocrinology and Metabolism. 2010;95:1846-50.

70. Nickolas TL, Jamal SA. Bone kidney interactions. Reviews in Endocrine \& Metabolic Disorders. 2015;16:157-63.

71. Wilson DM, Lee PD, Morris AH, Reiter EO, Gertner JM, Marcus R, Valerie E. Ron G. Growth hormone therapy in hypophosphatemic rickets. American Journal of Diseases of Children (1911). 1991;145:1165-70.

72. Cameron FJ, Sochett EB, Daneman A, Kooh SW. A trial of growth hormone therapy in well-controlled hypophosphataemic rickets. Clinical Endocrinology. 1999;50:577-82.

73. Haffner D, Nissel R, Wuhl E, Mehls O. Effects of growth hormone treatment on body proportions and final height among small children with X-linked hypophosphatemic rickets. Pediatrics. 2004;113:593-6.

74. Roy P, Martel J, Tenenhouse H. Growth hormone normalizes renal 1,25-dihydroxyvitamin D3-24-hydroxylase gene expression but not $\mathrm{Na}+-$ phosphate cotransporter (Npt2) mRNA in phosphatedeprived hyp mice. Journal of Bone and Mineral Research. 1997;12:1672-80.

75. Shimada T, Mizutani S, Muto T, Yoneya T, Hino R, Takeda S, Takeuchi Y, Fujita T, Fukumoto S, Yamashita T. Cloning and characterization of FGF23 as a causative factor of tumor-induced osteomalacia. Proceedings of the National Academy of Sciences of the United States of America. 2001;98:6500-5.

76. White KE, Carn G, Lorenz-Depiereux B, Benet-Pages A, Strom TM, Econs MJ. Autosomal-dominant hypophosphatemic rickets (ADHR) mutations stabilize FGF-23. Kidney International. 2001;60:2079-86.

77. Wöhrle S, Bonny O, Beluch N, Gaulis S, Stamm C, Scheibler M, Müller M, Kinzel B, Thuery A, Brueggen J, Hynes NE, Sellers WR, Hofmann F, Graus-Porta D. FGF receptors control vitamin D and phosphate homeostasis by mediating renal FGF-23 signaling and regulating FGF-23 expression in bone. Journal of Bone and Mineral Research. 2011;26:2486-97.
78. Li H, Martin A, David V, Quarles LD. Compound deletion of Fgfr3 and Fgfr4 partially rescues the hyp mouse phenotype. American Journal of Physiology. Endocrinology and Metabolism. 2011;300: 508-17.

79. Bai X, Miao D, Xiao S, Qiu D, St-Arnaud R, Petkovich M, Gupta A, Goltzman D, Karaplis AC. CYP24 inhibition as a therapeutic target in FGF23-mediated renal phosphate wasting disorders. The Journal of Clinical Investigation. 2016;126:667-80.

80. Wöhrle S, Henninger C, Bonny O, Thuery A, Beluch N, Hynes NE, Guagnano V, Sellers WR, Hofmann F, Kneissel M, Graus PD. Pharmacological inhibition of fibroblast growth factor (FGF) receptor signaling ameliorates FGF23-mediated hypophosphatemic rickets. Journal of Bone and Mineral Research. 2013;28:899-911.

81. Du E, Xiao L, Hurley MM. FGF23 neutralizing antibody ameliorates hypophosphatemia and impaired FGF receptor signaling in kidneys of HMWFGF2 transgenic mice. Journal of Cellular Physiology. 2016; doi:10.1002/jcp.25458.

82. Aono Y, Yamazaki Y, Yasutake J, Kawata T, Hasegawa H, Urakawa I, Fujita T, Wada M, Yamashita T, Fukumoto S, Shimada T. Therapeutic effects of anti-FGF23 antibodies in hypophosphatemic rickets/osteomalacia. Journal of Bone and Mineral Research. 2009;24:1879-88.

83. Ranch D, Zhang MYH, Portale AA, Perwad F. Fibroblast growth factor 23 regulates renal 1,25-dihydroxyvitamin D and phosphate metabolism via the MAP kinase signaling pathway in hyp mice. Journal of Bone and Mineral Research. 2011;26:1883-90.

84. Zhang MYH, Ranch D, Pereira RC, Armbrecht HJ, Portale AA, Perwad F. Chronic inhibition of ERK1/2 signaling improves disordered bone and mineral metabolism in hypophosphatemic (hyp) mice. Endocrinology. 2012;153:1806-16.

85. Imel EA, Zhang X, Ruppe MD, Weber TJ, Klausner MA, Ito T, Vergeire M, Humphrey JS, Glorieux FH, Portale AA, Insogna K, Peacock M, Carpenter TO. Prolonged correction of serum phosphorus in adults with $\mathrm{X}$-linked hypophosphatemia using monthly doses of KRN23. The Journal of Clinical Endocrinology and Metabolism. 2015;100:2565-73.

86. Carpenter TO, Imel EA, Ruppe MD, Weber TJ, Klausner MA, Wooddell MM, Kawakami T, Ito T, Zhang X, Humphrey J, Insogna KL, Peacock M. Randomized trial of the anti-FGF23 antibody KRN23 in X-linked hypophosphatemia. The Journal of Clinical Investigation. 2014;124:1587-97. 